\title{
Pyrometallurgical Removal of Arsenic from Electrostatic Precipitators Dusts of Copper Smelting
}

\author{
Hector Henao $^{1 *}$, Ignacio Paredes ${ }^{1}$, Rodrigo Diaz ${ }^{2}$, Javier Ortiz ${ }^{2}$ \\ ${ }^{1}$ Metallurgy Engineering Department, Technical University Federico Santa María, Av. España 1680, Postal Code 2340000 \\ Valparaíso, Chile \\ ${ }^{2}$ CODELCO, Ministro Hales Division, 48739 Antofagasta, Chile \\ Email: ‘hector.henao@usm.cl, ignacio.paredes@alumnos.usm.cl,RDiaz015@codelco.cl, JOrti027@codelco.cl
}

How to cite this paper: Henao, H., $\mathrm{Pa}$ redes, I., Diaz, R. and Ortiz, J. (2021) Pyrometallurgical Removal of Arsenic from Electrostatic Precipitators Dusts of Copper Smelting. Journal of Minerals and Materials Characterization and Engineering, 9, 545565 .

https://doi.org/10.4236/jmmce.2021.96036

Received: September 19, 2021

Accepted: November 2, 2021

Published: November 5, 2021

Copyright $\odot 2021$ by author(s) and Scientific Research Publishing Inc. This work is licensed under the Creative Commons Attribution International License (CC BY 4.0).

http://creativecommons.org/licenses/by/4.0/

\begin{abstract}
This work describes the experimental results of pyrometallurgical removing of arsenic from the dust collected in the electrostatic copper precipitators within the gas cleaning system of a Copper Flash Smelting Furnace. The generation of dust in the copper smelting worldwide ranges from $2-15 \mathrm{wt} \%$ per ton of a copper concentrate. In Chile, copper smelters produce approximately $110 \mathrm{kt} / \mathrm{y}$ of dust with a concentration of arsenic between 1 and $15 \mathrm{wt} \%$. The dust is a complex of metals oxides and sulfurs with copper concentrations greater than $10 \mathrm{wt} \%$ and relatively high silver concentrations. Since its high arsenic concentration, it is difficult to recover valuable metals through hydrometallurgical processes or by direct recirculation of the dust in a smelting furnace. Thus, the development of pyrometallurgical processes aimed at reducing the concentration of arsenic in the dust $(<0.5 \mathrm{wt} \%)$ is the main objective of this study, giving particular attention to the production of a suitable material to be recirculated in operations of copper smelting. The work provides a detailed characterization of the dust including the Quantitative Evaluation of Minerals by Scanning Electron Microscopy (QEMSCAN), Scanning Electron Microscope-Energy Dispersive X-ray Analysis (SEM/EDS), X-Ray Diffraction (XRD), the elemental chemical analysis using Atomic Adsorption (AAS), and X-Ray Fluorescence (X-RF). By considering that arsenic volatilization requires a process of sulfidation-decomposition-oxidation, this work seeks to explore the roasting of mixtures of copper concentrate/dust, sulfur/dust, and pyrrhotite/dust. By the elemental chemical analysis of the mixture after and before the roasting process, the degree of arsenic volatilization was determined. The results indicated the effects of parameters such as roasting temperature, gas flow, gas composition, and the ratio of mixtures (concen-
\end{abstract}


trate/dust, sulfur/dust, or pyrrhotite/dust) on the volatilization of arsenic. According to the findings, the concentration of arsenic in the roasted Flash Smelting dust can be reduced to a relatively low level $(<0.5 \mathrm{wt} \%)$, which allows its recirculation into an smelting process.

\section{Keywords}

Copper Smelter Dust, Electrostatic Precipitators of Copper, Removal of Arsenic, Sulfidation, Roasting Process

\section{Introduction}

In the copper smelting process, an important part of the arsenic contained in the copper concentrate is volatilized and then precipitated as fine particles in the Electrostatic Precipitator [1] [2] (in this work, this material will be referred as FS dust). Depending on the smelting technology and the specific condition of the smelter process, the amount of dust produced worldwide corresponds to between 2 and $15 \mathrm{wt} \%$ of the feed copper concentrate [3]. Chile produces approximately 15 million tons per year of copper concentrates, the existing smelters generating $110 \mathrm{kt} / \mathrm{y}$ of flue dusts with arsenic concentrations between $1-15 \mathrm{wt} \%$. Of this total, $85 \%$ is treated by leaching processes and the arsenic is disposed as scorodite together with $\mathrm{Sb}$ and other impurities [4] [5]. The literature reports the FS dust as a fine oxide-sulfide complex metal of $1-2 \mu \mathrm{m}$ of size, embedded in larger spherical particles of 8 to $10 \mu \mathrm{m}$ [6], with copper concentrations above $10 \mathrm{wt} \%$ and relative high silver content, which in some cases corresponds to $25 \%$ of the total inventories of elements in smelters [7].

Several processes propose recovering $\mathrm{Cu}$ and $\mathrm{Ag}$ from the dust, such as the leaching of dust with sulfuric acid and the stabilization of arsenic by hydrometallurgical treatments [8] [9] [10] [11]. The dust leaching process and the fixation of arsenic as scorodite are currently carried out at an industrial scale. The published industrial information claims that the produced scorodite is a nonhazardous waste and that the material is classified as non-reactive [12] [13]. The downsides of the processes include an expensive pretreatment for the oxidation of As (III) to As (V) and the uncertainty for the long-term stability of the scorodite [14] [15]. Furthermore, the leaching of dust with sulfuric acid, requires a comparatively high acid concentration $(>0.8 \mathrm{M})$ and high temperatures $\left(>80^{\circ} \mathrm{C}\right)$. In order to obtain $\mathrm{Cu}$ extractions above $60 \mathrm{wt} \%$, it is reported that the leaching process generates solid residues around $40 \mathrm{wt} \%$ with respect to the original material [16].

Pyrometallurgical processes to remove arsenic from FS dust produced in copper smelting are described in registered patents and publications [17] [18]. These included reactions of mixtures of the copper concentrate (or sulfur) and FS dust at temperatures between $500^{\circ} \mathrm{C}$ and $900^{\circ} \mathrm{C}$, producing a material with concentrations of $0.3 \mathrm{wt} \%$ of arsenic. Other patents and publications claim that the re- 
duction of the FS dust with coal or reducing gases of $\mathrm{CO}$ can volatilize arsenic [19] [20], obtaining calcines of less than $3 \mathrm{wt} \%$ of As ( $85 \mathrm{wt} \%$ arsenic volatilization) and a precipitate from the produced gas with a content of $\mathrm{As}_{2} \mathrm{O}_{3}$ above 90 $\mathrm{wt} \%$. One of the registered patents describes a process flowsheet where the dust is mixed with copper concentrate and processed in a roasting furnace, where the product is then recycled to a smelting furnace [21]. The pyrometallurgical processes described suggest the simultaneous reaction of sulfidation-decompositionoxidation.

The metallurgy industry considers arsenic content residues as waste materials. The literature reports different options for the disposal of the generated residues of arsenic, including encapsulation of arsenic trioxide in the Portland Cement [22], the production of scorodite discussed above [13] [14], and the production of glassy material with concentrations of arsenic up to $20 \mathrm{wt} \%$ [14] [15]. In terms of stability, the fixation of arsenic as a vitreous material can be considered the best option as it keeps the arsenic stable for geological periods of time [14].

Copper sulfide deposits worldwide exhibit an increasing concentration of arsenic. Experimental works related to the roasting processes of concentrates with high arsenic concentrations are reported in the literature [23] [24]. It is also reported an industrial operation where this kind of concentrate is treated in a Fluidized Bed Roaster producing a calcine with less than $0.5 \mathrm{wt} \%$ arsenic, which feeds a Flash Smelting Furnace. These studies had proposed mechanisms of reactions and evaluated the kinetics of decomposition and oxidation of $\mathrm{Cu}-\mathrm{As}-\mathrm{S}$ minerals in partial roasting of copper concentrates. However, the treatment and disposal of arsenic remains an unsolved international problem [4] [25]. Thus, it is imperative for the development of processes aimed at improving the treatment and disposal of arsenic. Although, hydrometallurgical processes are the main technological practice to treat metallurgical arsenic residues, the pyrometallurgical process for the treatment of metallurgical dust has the potential to increase the recovery of valuable metals $(\mathrm{Cu}$, precious metals) and generate a residual with high concentrations of dry arsenic oxide suitable for the production of glassy materials. Furthermore, contrary to the hydrometallurgical process, the material obtained after the volatilization of arsenic (materials with $<0.3 \mathrm{wt} \% \mathrm{As}$ ) can be recycled to the smelting furnace without additional solid waste being generated.

Despite the existing information of volatilization of arsenic from copper concentrates and metallurgical dust, the literature does not describe in detail the operational parameters. Furthermore, there are no available, in the reviewed literature, experiments or industrial practice for roasting of mixes of FS dust with concentrates with high concentration of arsenic. Thus, this work contributes to a better understanding of the suggested reduction-decomposition-oxidation processes by carrying out roasting experiments of a mixture of FS dust with copper concentrate with high concentration of arsenic. The work was complemented with experiments of roasting of mixtures of FS dust/sulfur, FS dust/pyrrhotite, or roasting of FS dust with sulfur dioxide. The work includes the microscopic and 
chemical characterization of the used copper concentrate, FS dust, and the products of roasting. The results obtained from the experimentation provided valuable information regarding the volatilization of arsenic in differing ranges of temperature, flow of gases, composition of gases, and mixtures of FS dust/concentrate. This information is intended to be a source of reference in the application of industrial processes and the development of roasting furnaces for the exclusive purpose of treating FS dust.

\section{Thermodynamics of Sulfidation-Decomposition-Oxidation Reactions}

Thermal decomposition of enargite $\left(\mathrm{Cu}_{3} \mathrm{AsS}_{4}\right)$ proposed the following reactions:

$$
\begin{gathered}
2 \mathrm{Cu}_{3} \mathrm{AsS}_{4}(\mathrm{~s})=3 \mathrm{Cu}_{2} \mathrm{~S}(\mathrm{~s})+\mathrm{As}_{2} \mathrm{~S}_{3}(\mathrm{~g})+\mathrm{S}_{2}(\mathrm{~g}) \\
4 \mathrm{Cu}_{3} \mathrm{AsS}_{4}(\mathrm{~s})=6 \mathrm{Cu}_{2} \mathrm{~S}(\mathrm{~s})+\mathrm{As}_{4} \mathrm{~S}_{4}(\mathrm{~g})+3 \mathrm{~S}_{2}(\mathrm{~g}) \\
4 \mathrm{Cu}_{3} \mathrm{AsS}_{4}(\mathrm{~s})=6 \mathrm{Cu}_{2} \mathrm{~S}(\mathrm{~s})+\mathrm{As}_{4}(\mathrm{~g})+5 \mathrm{~S}_{2}(\mathrm{~g})
\end{gathered}
$$

The analysis of Reactions (1), (2), and (3) indicated spontaneity at temperatures exceeding $470^{\circ} \mathrm{C}[16]$.

The oxidation of enargite was described by the following chemical reactions [23] [24]:

$$
\begin{aligned}
& 2 \mathrm{Cu}_{3} \mathrm{AsS}_{4}(\mathrm{~S})+13 / 2 \mathrm{O}_{2}(\mathrm{~g})=\mathrm{As}_{2} \mathrm{O}_{3}(\mathrm{~g})+3 \mathrm{Cu}_{2} \mathrm{~S}(\mathrm{~s})+5 \mathrm{SO}_{2}(\mathrm{~g}), \\
& \Delta \mathrm{G}^{\circ}\left(700^{\circ} \mathrm{C}\right)=-141.4 \mathrm{~kJ} / \mathrm{mol} \mathrm{As}_{2} \mathrm{O}_{3}
\end{aligned}
$$

The reaction at $700^{\circ} \mathrm{C}$ indicates the formation of $\mathrm{As}_{2} \mathrm{O}_{3}(\mathrm{~g})$.

The reaction of sulfidation of arsenic oxide was represented by the reaction [24] [26].

$$
\begin{aligned}
& \mathrm{As}_{2} \mathrm{O}_{3}(\mathrm{~g})+3 \mathrm{Cu}_{2} \mathrm{O}(\mathrm{s})+11 / 2 \mathrm{~S}_{2}(\mathrm{~g})=2 \mathrm{Cu}_{3} \mathrm{AsS}_{4}(\mathrm{~s})+3 \mathrm{SO}_{2}(\mathrm{~g}), \\
& \Delta \mathrm{G}^{\circ}\left(700^{\circ} \mathrm{C}\right)=-117 \mathrm{~kJ} / \mathrm{mol} \mathrm{As} \mathrm{O}_{3}
\end{aligned}
$$

Thus, it is expected that the arsenic contained in enargite will volatilize by decomposition and simultaneously oxidize at the temperatures of operation of a Fluidized Bed Roaster Furnace of $700^{\circ} \mathrm{C}$.

The equilibrium between arsenic trioxide $(1 \mathrm{~mol})$ with $\mathrm{S}_{2}(\mathrm{~g})(1.5 \mathrm{moles})$, considering a total pressure of $1 \mathrm{~atm}$, was simulated at temperatures between $500^{\circ} \mathrm{C}$ and $700^{\circ} \mathrm{C}$ using the thermodynamic package FactSage 7.1 (databases FactPS and FToxide). There were many reactions involved in this calculation. However, it is possible to consider the following reactions as the main ones:

$$
\begin{gathered}
\mathrm{As}_{2} \mathrm{O}_{3}+\mathrm{S}_{2}=2 \mathrm{AsS}+3 / 2 \mathrm{O}_{2} \\
\mathrm{As}_{2} \mathrm{O}_{3}+3 / 2 \mathrm{~S}_{2}=\mathrm{As}_{2} \mathrm{~S}_{3}+3 / 2 \mathrm{O}_{2} \\
1 / 2 \mathrm{~S}_{2}+\mathrm{O}_{2}=\mathrm{SO}_{2}
\end{gathered}
$$

The results of the simulation for the partial pressure of main gaseous compounds are shown in Figure 1. The results indicated that $\mathrm{As}_{4} \mathrm{~S}_{4}$ and $\mathrm{As}_{4} \mathrm{O}_{6}$ gases were the most predominant arsenic species, whose partial pressures were around $0.2 \mathrm{~atm}$. 


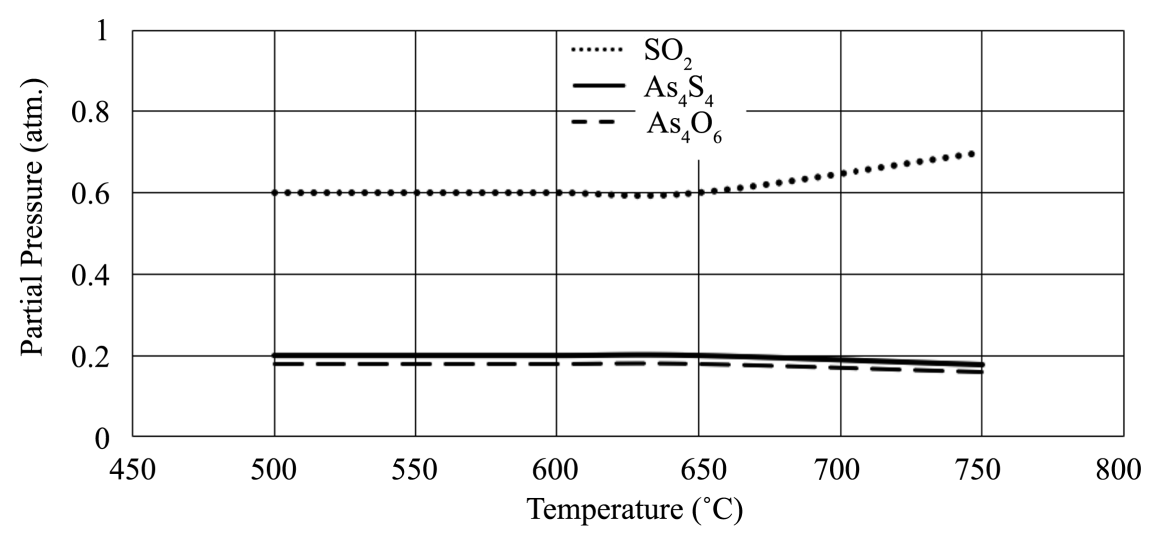

Figure 1. Relationship between partial pressure of $\mathrm{As}_{4} \mathrm{O}_{6}, \mathrm{As}_{4} \mathrm{~S}_{4}$, and $\mathrm{SO}_{2}$ versus temperature for the equilibrium $\mathrm{As}_{2} \mathrm{O}_{3} / \mathrm{S}_{2}$.

According to the thermodynamic analysis of Reactions (1) - (8), a sulfidation-decomposition-oxidation process is possible if a material containing arsenic oxides (FS dust) is mixed and roasted with other material (copper sulfides, pyrrhotite, elemental sulfur, or $\mathrm{SO}_{2}$ ), which has the potential to generate the partial pressure of $\mathrm{S}_{2}$ required during the sulfidation process.

However, as will be indicated in the section of FS dust characterization, arsenic oxides are only a component of the species reported by the XRD and SEM/ EDS analysis. Therefore, experimentation is required to verify that the FS dust reacts according to the thermodynamic predictions. Most of the roasting experiments used a mixture of FS dust produced in a Flash Smelting Furnace and copper concentrate. The characterization of each material is described in the following sections.

\section{Materials and Methods}

The materials used in the experiments correspond to mixtures of copper concentrate/dust, sulfur/dust, pyrrhotite/dust. Sulfur and pyrrhotite were used as grade reactive, whereas copper concentrate and dust were obtained from a copper smelter operation. The elemental and mineralogical compositions of the copper concentrate and dust were obtained by QEMSCAN (TSCAN, Model: VEGA3 LM), XRD (XRD STOE, Model: STADI_MP, Detector DECTRIS MYThem 1K, Database Match), SEM/EDS (SEM: Zeiss Evo Model: MA10, EDS: Oxford X-Act, Detector BS, Software INCA), XR-F and AAS (AAS Perkin Elmer, Model: PinAAcle 900F Flame).

\subsection{Copper Concentrate with High Arsenic Concentration}

A copper concentrate from the northern zone of Chile with high concentrations of arsenic $(\sim 5 \mathrm{wt} \%)$ was used as a material in this work. Given the important role of this copper concentrate in the present investigation, a set of experiments were carried out to determine the effect of temperature and time in the removal of arsenic during roasting. 
The characterization of the concentrate sample indicates that arsenic is contained in minerals of enargite/tennantite $\left(\mathrm{Cu}_{3} \mathrm{AsS}_{4} / \mathrm{Cu}_{12} \mathrm{As}_{4} \mathrm{~S}_{13}\right)$. The AAS elemental composition analysis of the sample reported $42.1 \mathrm{wt} \%$ for $\mathrm{Cu}, 11.1 \mathrm{wt} \%$ Fe, 30.0 wt\% S and 5.23 wt\% As. The main observed minerals were Chalcocite/ Digenite, Enargite/Tennantite and Pyrite. In minor proportion are present Chalcopyrite and Bornite. Complete elemental chemical and mineralogical analysis information is included in complementary information Annex 1.

\subsection{FS Dust}

The focal subject in this study is the treatment of the FS dust. Thus, this section includes a detailed analysis of elemental and mineralogical composition. Table 1 indicates that the main elemental composition of the FS dust is copper, iron, sulfur, arsenic and zinc. The analyzed sample also include a number of minor elements, among them a relative high concentration of silver.

The size distribution of an RP dust (Mastersizer 3000 laser diffraction particle size analyzer, water as dispersant) of Figure 2 shows indicated that a fraction of 0.8 of the sample corresponds to size under $22 \mathrm{~mm}$ and $90 \mathrm{wt} \%$ to size under 42 $\mathrm{mm}$.

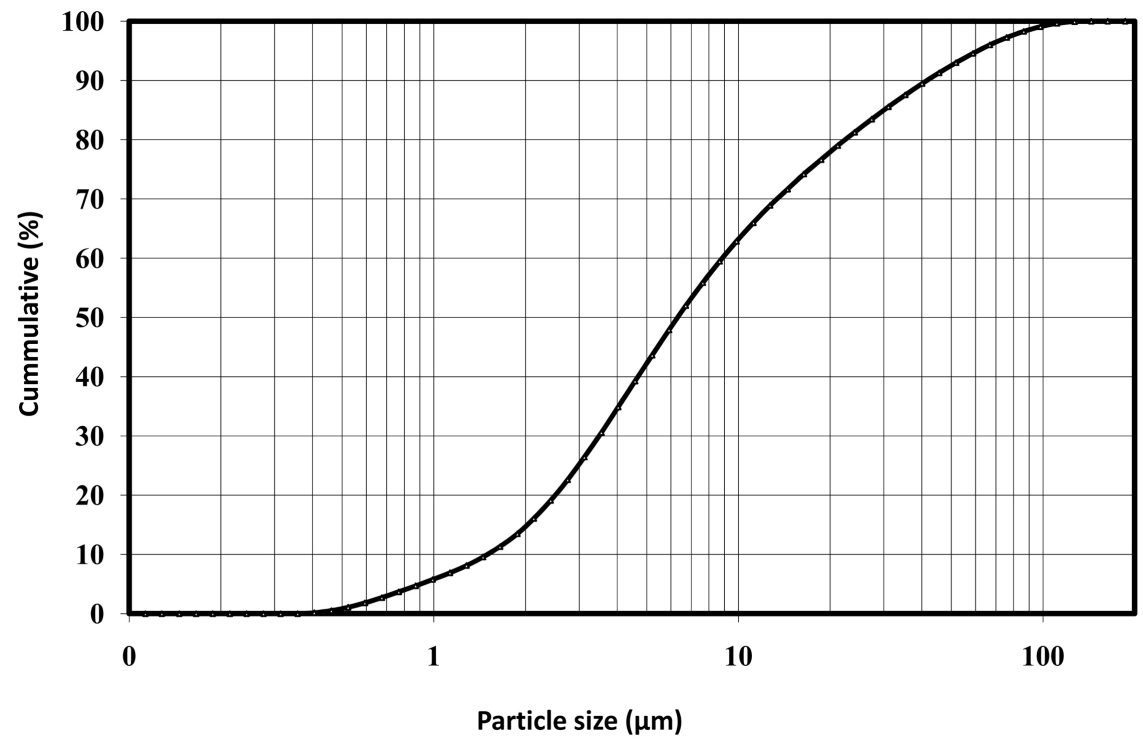

Figure 2. RP dust sample particles size distribution (Mastersizer 3000 laser diffraction particle size analyzer, water as dispersant).

Table 1. Elemental chemical analysis (wt\%) of the FS dust with high concentrations of arsenic by AAS and XRF.

\begin{tabular}{lcccccccccccccccc}
\multicolumn{1}{l}{} & $\mathrm{Cu}$ & $\mathrm{Fe}$ & $\mathrm{S}$ & $\mathrm{As}$ & $\mathrm{Zn}$ & $\mathrm{Si}$ & $\mathrm{Pb}$ & $\mathrm{K}$ & $\mathrm{Na}$ & $\mathrm{Al}$ & $\mathrm{Ca}$ & $\mathrm{Mo}$ & $\mathrm{Sb}$ & $\mathrm{Mn}$ & $\mathrm{P}$ & $\mathrm{Ag}$ \\
& 24.8 & 12.9 & 9.7 & 5.2 & 3.3 & 2.1 & 0.09 & 1.12 & 0.22 & 0.7 & 0.38 & 0.18 & 0.06 & 0.02 & 0.04 & 279 \\
\hline & $\mathrm{Cd}$ & $\mathrm{Ti}$ & $\mathrm{Ge}$ & $\mathrm{Sn}$ & $\mathrm{Pb}$ & $\mathrm{Bi}$ & & & & & & & & & & \\
$\mathrm{XRF}$ & & & & & & & & & & & & & & & & \\
& 0.15 & 0.03 & 0.02 & 0.02 & 0.02 & 0.29 & & & & & & & & & & \\
\end{tabular}


Figure 3 shows a set of SEM micrographs of FS dust, indicating the presence in the sample of a glassy matrix in the range of size of $100 \mu \mathrm{m}$ (Figure 3(a)) and apparently agglomerates of complex oxide material (Figure $3(d)$ ). The elemental chemical composition of selected points (analyzed by EDS) shown in Table 2, indicated that arsenic is present in the glassy matrix and in some of the complex $\mathrm{Fe}-\mathrm{Cu}-\mathrm{Zn}$-As oxide. Except for the iron oxide observed in the glassy matrix in form of dendrites, it was not possible to identify another kind of crystals at the used magnification of the SEM.

$\mathrm{XRD}$ analysis identified among others peaks of calcocianite $\left(\mathrm{Cu}_{2} \mathrm{SO}_{4}\right)$, hematite $\left(\mathrm{Fe}_{2} \mathrm{O}_{3}\right)$, tenorite $(\mathrm{CuO})$, quartz $\left(\mathrm{SiO}_{2}\right)$ and arsenolite $\left(\mathrm{As}_{2} \mathrm{O}_{3}\right)$. XRD diffractgram is included in Annex 2.

\subsection{Experimental Method}

The experiments included the roasting of copper concentrates and the roasting of a mixture of copper concentrate/FS dust, sulfur/FS dust, pyrrhotite/FS dust, and $\mathrm{FS}$ dust in an atmosphere of $\mathrm{SO}_{2}$ gas. Figure 4 describes the experimental equipment. The arrangement aims to achieve a uniform mixture of gases with
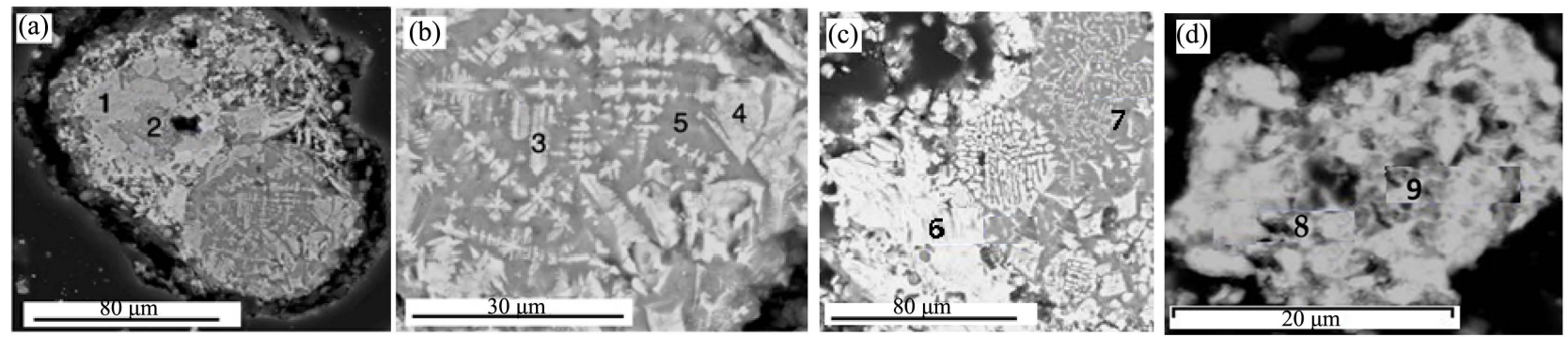

Figure 3. Scanning electron micrograph of FS dust. (a) and (b) glassy matrix and iron oxides, (c) and (d) complex Fe-Cu-Zn-As oxide phases and glassy matrix.

Table 2. SEM/EDS analysis of points of Figure 3 of FS dust (analysis condition: Acceleration voltage $=15 \mathrm{kV}$, beam current $=11$ $\mathrm{nA})$.

\begin{tabular}{|c|c|c|c|c|c|c|c|c|c|c|c|c|}
\hline \multirow{2}{*}{ Phase } & \multirow{2}{*}{$\begin{array}{c}\text { Analyzed } \\
\text { point }\end{array}$} & \multicolumn{11}{|c|}{ Composition (wt\%) } \\
\hline & & $\mathrm{O}$ & $\mathrm{Al}$ & $\mathrm{Si}$ & S & $\mathbf{K}$ & $\mathrm{Ca}$ & $\mathrm{Fe}$ & $\mathrm{Cu}$ & $\mathrm{Zn}$ & As & $\mathrm{Sb}$ \\
\hline \multirow{6}{*}{$\mathrm{Cu}-\mathrm{Fe}-\mathrm{O}-\mathrm{S}-\mathrm{As}-\mathrm{Zn}-\mathrm{Al}-\mathrm{Si}-\mathrm{K}-\mathrm{Sb}$} & 7 & 37.1 & 1.4 & 9.5 & 0.5 & 0.5 & & 42.1 & 4.8 & 1.2 & 1.9 & 1.1 \\
\hline & 2 & 40.7 & 1.8 & 11.7 & & 0.5 & & 27.5 & 9.2 & 6.4 & 2.2 & \\
\hline & 5 & 43.4 & 1.8 & 14.9 & 0.3 & 0.3 & 0.32 & 24.8 & 1.5 & 10.2 & 1.1 & 0.9 \\
\hline & 8 & 35.0 & & & & & & 22.0 & 21.4 & 0.6 & 16.0 & 5.1 \\
\hline & 9 & 34.3 & & & & & & 34.1 & 16.1 & & 10.8 & 4.7 \\
\hline & 6 & 18.1 & & & 1.1 & & & 2.6 & 48.9 & 2.3 & 27.0 & \\
\hline \multirow{3}{*}{ Fe oxide } & 3 & 39.4 & 2.5 & 5.3 & & & & 46.5 & 4.0 & 2.0 & & \\
\hline & 4 & 35.4 & 2.1 & 3.7 & & & & 44.9 & 2.1 & 11.3 & & \\
\hline & 1 & 32.2 & & & & & & 54.1 & 5.2 & 3.2 & 5.4 & \\
\hline
\end{tabular}




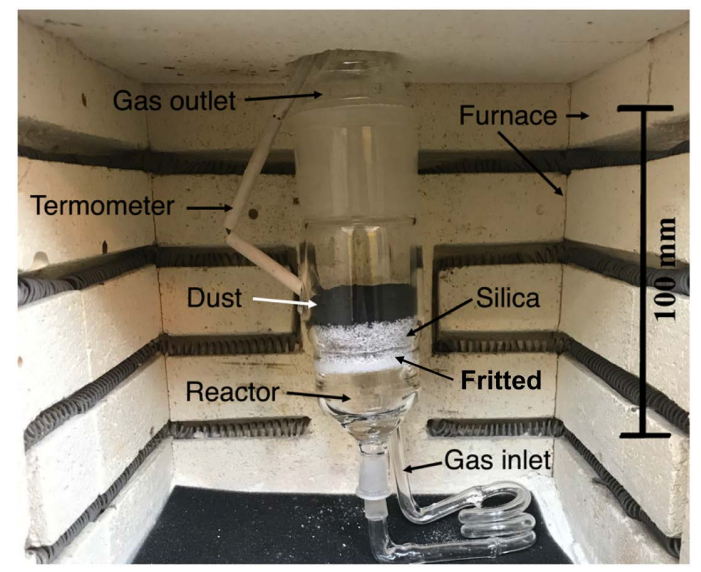

Figure 4. Experimental equipment.

the sample, as well as a stable temperature for both of the gases and the sample in such a way that it reproduces the conditions of an industrial Fluidized Bed Roaster.

The reactor was constructed from a boron silicate glass resistant to temperatures up of $750^{\circ} \mathrm{C}$, an installed fritted glass disk formed the base for the bed of the reactor. In order to guarantee a uniform distribution of gas and obtain a homogeneous temperature of the gas and sample, $5 \mathrm{~g}$ of silica with a range of sizes between 100 and $200 \mathrm{~mm}$ was used as a bed in the reactor. FS dusts were mixed with the concentrate (or elemental sulfur, or pyrrhotite) depending on the experiment that was being carried out and the $5 \mathrm{~g}$ sample was then placed on top of the bed of silica. The muffle, placed under a fume hood, was preheated to $200^{\circ} \mathrm{C}$, where the reactor was installed inside. A stream of nitrogen of $20 \mathrm{~mL} / \mathrm{min}$ was circulated to avoid oxidation of the sample. The muffle temperature was then increased until it reached a selected working temperature. At this time, the nitrogen current was changed by a determined air or $\mathrm{SO}_{2}$ flow (for example 10 $\mathrm{mL} / \mathrm{min}$ ) and the experiment time measurement began.

Once the roasting time had ended, the nitrogen current was switched on and the temperature of the muffle was reduced to extract the sample from the reactor. The sample, once extracted from the reactor, was separated in a screen of 200 meshes. The oversized material contained the silica and the under size contained the calcined sample. The oversized material containing the silica bed was analyzed, reporting concentrations of iron and copper $<0.5 \mathrm{wt} \%$ and arsenic $<$ $0.05 \mathrm{wt} \%$, this indicated a good separation between the silica material used as the bed and the calcined sample.

During the tests, the temperature was controlled with a thermocouple type $\mathrm{K}$ in a range of $\pm 5^{\circ} \mathrm{C}$. The elemental composition of the samples was determined by Atomic Absorption, whilst, the sulfur content was determined using a LECO equipment (analyzed by Australia Laboratory Service-Chile).

The percentage of the volatilization of species (As) was defined as:

$$
\% \text { Volatilization As }=100 \times\left([\mathrm{wt} \% \mathrm{As}]_{\text {initial }}-[\mathrm{wt} \% \mathrm{As}]_{\text {final }}\right) /[\mathrm{wt} \% \mathrm{As}]_{\text {initial }}
$$


where $[\mathrm{wt} \% \mathrm{As}]_{\text {initial }}$ was the concentration of arsenic measured in the loaded sample and $[\mathrm{wt} \% \mathrm{As}]_{\text {final }}$ was the concentration of arsenic measured for the sample after the roasting process.

The volatilization percentage was defined in terms of the percentage wt $\%$ and not by the total mass balance of the element under analysis. The reason for this is that the total weight of the sample does not change appreciably during the roasting process. In addition, it was difficult to quantify the amount of sample lost during its manipulation, the loss of sample in the conduct of gases during the process, and a possible contamination of the sample with silica. This contamination is inevitable due to friction between the grains in the fluidized state.

\section{Results}

The experimental plan was committed foremost on the study of a mixture of copper concentrate with high contents of arsenic and FS dust. The first set of experiments was carried out using a copper concentrate to evaluate which conditions of the roasting process allowed the greatest volatilization of arsenic, these result were used as a base case. Roasting times and temperatures were the variables to consider in this context. Based on this information, a second set of experiments for the mixtures concentrate/FS dust were designed. Experimental conditions, details of elemental chemical analysis and QEMSCAN results for selected samples are included in Annex 3.

\subsection{Results of Roasting the Concentrate with High Concentration of Arsenic}

The volatilization of arsenic for the concentrate under different conditions of temperature and time for the roasting process were carried out under a constant airflow rate of $10(\mathrm{~mL} / \mathrm{min})$. Injected gas flow levels above $10(\mathrm{~mL} / \mathrm{min})$ did not show an appreciable increase in arsenic volatilization.

Figure 5 indicated a high volatilization of arsenic $(>90 \%)$ in air, even at $600^{\circ} \mathrm{C}$. Whereas, a low volatilization $(<50 \mathrm{wt} \%)$ was obtained in an atmosphere of nitrogen at temperatures below $650^{\circ} \mathrm{C}$. The results were in accordance with

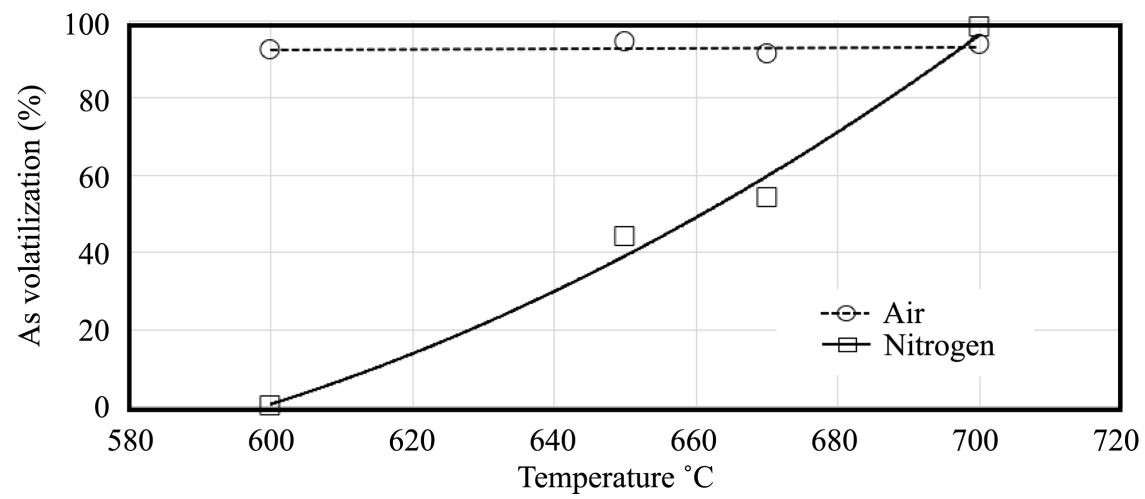

Figure 5. Relationship between temperature and arsenic volatilization for roasting of the copper concentrate in an air or nitrogen atmosphere (roasting time: $15 \mathrm{~min}$ ). 
thermodynamic calculations, where the volatilization by oxidation occurs spontaneously at the low temperature of $600^{\circ} \mathrm{C}$ [23]. While, simultaneous decomposition for the reactions (1) - (3) took place at a temperature above $630^{\circ} \mathrm{C}$ [23] [24]. The results were also in congruence with kinetic results from reported experiments, where at $5 \mathrm{~min}$ of roasting, an appreciable thermal decomposition of enargite occurred with volatilization of arsenic around $70 \mathrm{wt} \%$ at a temperature of $675^{\circ} \mathrm{C}$ and less than $25 \mathrm{wt} \%$ at a temperature of $625^{\circ} \mathrm{C}$ [23]. It was apparent in Figures 5-7 that roasting in air at temperatures between 600 and $700^{\circ} \mathrm{C}$ had a marginal effect on the volatilization of arsenic and on the final concentration of sulfur. Also, the volatilization of arsenic increased at a high rate until it approached a time of $5 \mathrm{~min}$. Then, the volatilization stabilized at a value of around $90 \mathrm{wt} \%$, with a concentration of arsenic in the calcine between 0.2 and $0.5 \mathrm{wt} \%$. With temperature of $650^{\circ} \mathrm{C}$ and a time of $15 \mathrm{~min}$, the volatilization of arsenic was close to $96 \%$. Figure 7 shows that the sulfur concentration decreased over time and is almost independent to temperature in the range between $600^{\circ} \mathrm{C}$ to $700^{\circ} \mathrm{C}$, reporting values of around $20 \mathrm{wt} \%$ at $5 \mathrm{~min}$. Given this characteristic, in the figure was included a line of tendency taking in consideration all the experimental results of this set.

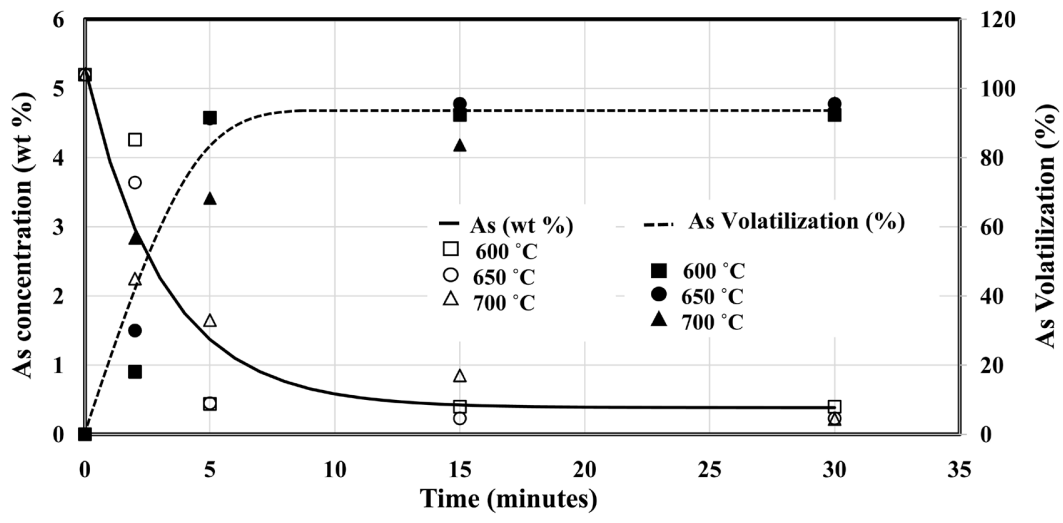

Figure 6. Volatilization of arsenic for the copper concentrate under different conditions of temperature and time of the roasting process.

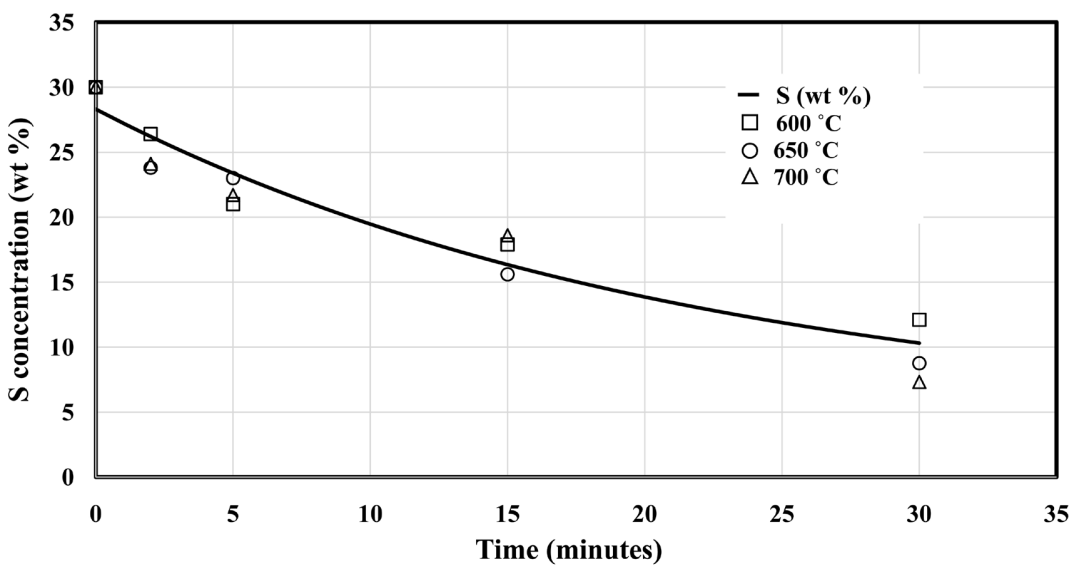

Figure 7. Sulfur in the copper concentrate under different times of the roasting process 
The results of QEMSCAN for experiment at $650^{\circ} \mathrm{C}$ and a roasting time of 15 min indicate an effective volatilization of arsenic. The predominant sulfur compound was bornite while enargite was reduced to $0.2 \mathrm{wt} \%$.

\subsection{Copper Concentrate/FS Dust Mixture Roasting}

A second set of experiments were carried out at $650^{\circ} \mathrm{C}$ aimed to find the ratio of the copper concentrate/FS dust mixture that would allow a high volatilization of the arsenic with the highest amount of FS dust in the mixture. The results are plotted in Figure 8, (numerical information was included in Table A6, Annex 4) which include the results of a mass balance calculated considering zero volatilization of arsenic from the dust of the mixture and a volatilization of arsenic in the concentrate of $95.8 \%$. Volatilization of arsenic from the mixture is negligible up to a ratio of 30/70, furthers studies would be required in order to provide an explanation for this phenomenon. By comparing the lines of tendency of the figure, arsenic volatilization of FS dust is possible only for mixtures with ratios of copper concentrate/FS dust above 50/50. A total volatilization of arsenic in the sample of around $80 \%$ was obtained at a ratio of $75 / 25$. Thus, the results indicates that from an operational point of view, a large ratio of copper concentrate/FS dust would be required to volatilize the arsenic contained in the FS dust and a ratio of 75/25 is effective to reach a high volatilization from the FS dust.

A third set of experiments were carried out keeping a ratio of the copper concentrate/FS dust mixture of 75/25 to evaluate how time and temperature can affect the volatilization of arsenic during the roasting process. The results, shown in Table 3, indicate that at a temperature of $650^{\circ} \mathrm{C}$ and a roasting time of $5 \mathrm{~min}$, the volatilization of arsenic reached a value of $90 \mathrm{wt} \%$. At the temperature of $700^{\circ} \mathrm{C}$, the volatilization of arsenic reached a value between of $95 \mathrm{wt} \%$. A QEMSCAN analysis for the experiment at $700^{\circ} \mathrm{C}$ and 15 minutes was included in Table A7 Annex 4. The results indicated a low concentration of arsenic (outside the detection limit of the equipment), a concentration of $\mathrm{Cu}$ of $48.5 \mathrm{wt} \%$ and sulfur $8.2 \mathrm{wt} \%$. Longer roasting times of 5 minutes or increasing temperature from $650^{\circ} \mathrm{C}$ to $700^{\circ} \mathrm{C}$ shown marginal effect in the volatilization of arsenic. The values ranging between $93 \%$ and $95 \%$ (a difference of $2 \%$ ) is between the errors of the experimental work.

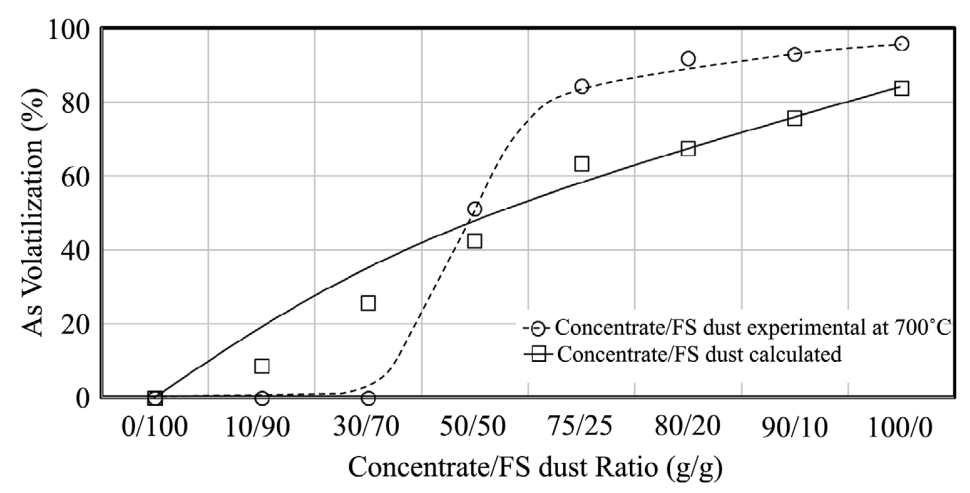

Figure 8. Effect of the copper concentrate/FS dust mixture ratio on the volatilization of arsenic and calculated data considering zero volatilization of arsenic from the dust at $700^{\circ} \mathrm{C}$. 
A last set of experiments included roasting of mixtures of sulfur/FS dust, pyrrhotite/FS dust, and roasting with nitrogen and air. The results are summarized in Table 4 and Table 5, the mixture sulfur/FS dust reported a volatilization of the order of $10 \mathrm{wt} \%$, for the mixture pyrrhotite/FS dust volatilization of arsenic reach values of around $50 \mathrm{wt} \%$ in the sample.

Figure 9 summarize the results at $700^{\circ} \mathrm{C}$ by comparing the $\%$ of volatilization of arsenic at differing mixtures and atmosphere of gases. It shows that the most effective volatilization occur for the mixture of concentrate/FS dust, also pyrrhotite/FS dust look promissory.

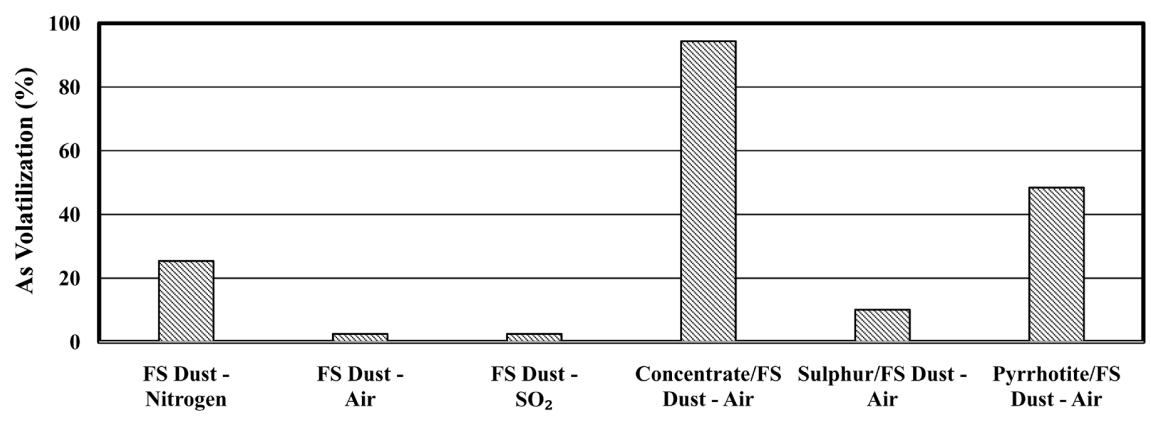

Figure 9. Volatilization of arsenic using different sources to the sulfidation process at $700^{\circ} \mathrm{C}$.

Table 3. Volatilization of arsenic for a mixture concentrate/FS dust of $75 / 25$, under different temperatures and roasting times.

\begin{tabular}{ccccc}
\hline Mixture & $\begin{array}{c}\text { Time } \\
\text { minutes }\end{array}$ & $\begin{array}{c}\text { Temperature } \\
{ }^{\circ} \mathrm{C}\end{array}$ & $\begin{array}{c}\text { Final As } \\
\text { wt\% }\end{array}$ & $\begin{array}{c}\text { As Volatilization } \\
\text { wt\% }\end{array}$ \\
\hline Initial dust & & & 5.38 & \\
& 5 & 650 & 0.49 & 90.9 \\
Copper & 15 & 650 & 0.37 & 93.1 \\
concentrate/FS dust & 30 & 650 & 0.30 & 94.4 \\
$75 / 25$ (wt\%/wt\%) & 5 & 700 & 0.26 & 95.2 \\
& 15 & 700 & 0.31 & 94.2 \\
& 30 & 700 & 0.26 & 95.2 \\
\hline
\end{tabular}

Table 4. Volatilization of arsenic for a mixture sulfur/FS dust at a weight ratio 5/95 under different temperatures and roasting times of 15 minutes.

\begin{tabular}{ccc}
\hline $\begin{array}{c}\text { Temperature } \\
{ }^{\circ} \mathrm{C}\end{array}$ & $\begin{array}{c}\text { Final As } \\
\text { wt\% }\end{array}$ & $\begin{array}{c}\text { As Volatilization } \\
\text { wt\% }\end{array}$ \\
\hline 600 & 4.5 & 13.9 \\
650 & 4.6 & 12.0 \\
700 & 4.7 & 10.1 \\
\hline
\end{tabular}


Table 5. Effect of the roasted sample material and flow gas used on the arsenic volatilization at $650^{\circ} \mathrm{C}$.

\begin{tabular}{cccccccccc}
\hline & & \multicolumn{4}{c}{$\begin{array}{c}\text { Composition } \\
\text { Roasted sample }\end{array}$} & $\begin{array}{c}\text { Flow } \\
\text { Gas Used }\end{array}$ & \multicolumn{4}{c}{$\begin{array}{c}\text { Volatilization } \\
\text { (wt\%) }\end{array}$} \\
\cline { 3 - 9 } & & Cu & Fe & S & As & Sb & As & Sb \\
\hline FS dust & Nitrogen & 31.0 & 12.0 & 3.7 & 3.9 & 0.3 & 25.4 & 70.0 \\
FS dust & Air & 24.1 & 12.9 & 7.7 & 5.1 & N/A & 2.5 & N/A \\
$\begin{array}{c}\text { Sulfur/FS dust } \\
5 / 95 \text { (wt\%/wt\%) }\end{array}$ & Air & N/A & N/A & N/A & 4.7 & 0.2 & 10.1 & 80.0 \\
$\begin{array}{c}F_{7} \mathrm{~S}_{8} / \mathrm{FS} \text { dust } \\
10 / 95(\mathrm{wt} \% / \mathrm{wt} \%)\end{array}$ & Air & N/A & N/A & N/A & 2.7 & 0.1 & 48.4 & 90.0 \\
\hline
\end{tabular}

N/A: No analyzed.

Chemical analysis of antimony was included in selected experiments, the results are shown in Table 4, it is observed that this element volatilizes above 70\% at the analyzed experimental conditions.

\section{Conclusions}

Scanning electron microscope images and SEM/EDS of FS dust indicated that it is mainly composed of particles with sizes between 10 and $100 \mu \mathrm{m}$, with a glassy matrix and crystals of iron oxides. The arsenic was found in the glassy matrix, in complex Fe-Cu-Zn-As-O-S-(and other elements) oxide phases such as calcocianite, hematite, tenorite, quartz and arsenolite. In the literature, the FS dust is characterized as small amorphous particles of arsenic oxides. Based on the results of SEM/EDS, it is plausible to hypothesize that the arsenic present in the gases inside the Flash Smelting Furnace interacts with the suspended particles of liquid slag $(<100 \mu \mathrm{m}$ in size). When the exhausted gases cool, a glassy matrix in arsenic appears. The arsenic in the gas also precipitates as complex oxides. Further investigation will be necessary to obtain evidence of these interactions.

The results of roasting the copper concentrated with high concentrations of arsenic were in accordance with the results reported in the literature for thermal decomposition and oxidation of enargite. The main contribution of the experiments carried out for this material revealed that to obtain a high volatilization of arsenic, the roasting process had better to take place at temperatures of $700^{\circ} \mathrm{C}$.

The data obtained through this work indicated that the arsenic present in the FS dust can be volatilized through roasting a mixture of copper concentrate/FS dust at temperatures above $600^{\circ} \mathrm{C}$ and roasting times that are less than $5 \mathrm{~min}$. The mixing to roaster requires a weight ratio of copper concentrate/FS dust greater than 50/50. At an industrial level, it would be effective to take this process in a concentrate roasting furnace and then recirculate it in the copper smelting process.

The results obtained for antimony indicated that this element also volatilizes with nitrogen and the mixture of Sulfur/FS dust and $\mathrm{Fe}_{7} \mathrm{~S}_{8} / \mathrm{FS}$ dust. Additional 
experiments will be required to evaluate the volatilization with concentrate.

There were interesting findings where the arsenic volatilization was not effective for the pyrrhotite/FS dust mixture and sulfur/FS dust mixture. Considering that both materials, sulfur and pyrrhotite, generate a high partial pressure of $\mathrm{SO}_{2}$, an explanation was not found for the fact that the sulfidation-decomposition-oxidation process did not occur with the same success obtained at the mixture copper concentrate/FS dust. Thus, a more extensive and detailed experimental research would be required for these materials to confirm what was found.

The removal of arsenic by means of a sulfidation-decomposition-oxidation process from the copper concentrate/FS dust mixtures was analyzed using SEM/ EDS, in order to find the formation of "fresh" enargite-tenantite crystals, which were not detected. A more detailed experiment and SEM/EDS, XRD, and QEMSCAN characterization will be required to detect the possible formation of crystals of enargite-tenantite. However, given the successful volatilization of arsenic reported in the experimental results, it is possible to consider that the sulfidation-decomposition-oxidation occurs simultaneously without the formation of these crystals.

Future research may be directed to the design of a roasting furnace dedicated to the roasting of mixtures of copper concentrate/FS dust, the study will require estimating the amount of concentrate necessary to have an autogenous roasting process.

\section{Authors' Contributions}

Conceptualization, H.H., R.D., and J.O.; methodology, H.H.; formal analysis, H.H. and R.D.; investigation, H.H. and I.P.; resources, R.D. and J.O.; writing and editing, H.H.; supervision, H.H., R.D., and J.O.; funding acquisition, R.D. and J.O.

\section{Conflicts of Interest}

The authors declare no conflict of interest. The funders had no role in the design of the study; in the collection, analyses, or interpretation of data; in the writing of the manuscript, or in the decision to publish the results.

\section{References}

[1] Parker, K.R. (1997) Applied Electrostatic Precipitation. Blackie Academic \& Professional, London, 375-376. https://doi.org/10.1007/978-94-009-1553-4 1

[2] King, M.J., Davenport, W.G. and Moats, M.S. (2013) Sulfuric Acid Manufacturing. 2nd Edition, Elsevier, New York, 35-37.

[3] Wood Mackenzie Energy Research \& Consultancy (2017) Copper Smelter Technical Parameters. https://www.woodmac.com

[4] Valenzuela, I. (2018) Trends and Treatments of Impurities in Copper Mining. Proceedings of the International Seminar on Impurities in Copper Raw Material, Tokyo, 16-17 October 2018

[5] Montenegro, V., Sano, H. and Fujisawa, T. (2010) Efecto de la recirculación de polvo 
de fundición de cobre de Chile con altos contenidos de impurezas en la distribución de impurezas durante el proceso de fusión. Revista de Metalurgia, 46, 69-77. https://doi.org/10.3989/revmetalm.0919

[6] Okanigbe, D.O., Popoola, A.P.I. and Adeleke, A.A. (2017) Characterization of Copper Smelter Dust for Copper Recovery. Procedia Manufacturing, 7, 121-126. https://doi.org/10.1016/j.promfg.2016.12.032

[7] Muñoz, E. (2019) Deficiencias en el Tratamiento de Fases de la Fundición Potrerillos, División Salvador-CODELCO. Bachelor's Thesis, Universidad Técnica Federico Santa María, Valparaíso.

[8] Alguacil, F.J., Magne, L., Navarro, P. and Simpson, J. (1996) Tratamiento hidrometalúrgico de los polvos de fundición de cobre. Desarsenificaciòn de las disoluciones de lixiviación. Revista de Metalurgia (Madrid), 32, 400-407. https://doi.org/10.3989/revmetalm.1996.v32.i6.888

[9] Sahu, N.K., Dash, B., Sahu, S., Bhattacharya, I.N. and Subbaiah, T. (2012) Extraction of Copper by Leaching of Electrostatic Precipitator Dust and Two Step Removal of Arsenic from the Leach Liquor. Korean Journal of Chemical Engineering, 29, 1638 1642. https://doi.org/10.1007/s11814-012-0081-5

[10] Nazari, A.M., Radzinski, R. and Ghahreman, A. (2017) Review of Arsenic Metallurgy: Treatment of Arsenical Minerals and the Immobilization of Arsenic. Hydrometallurgy, 174, 258-281. https://doi.org/10.1016/j.hydromet.2016.10.011

[11] Liu, Z.-X., et al. (2018) Removal of Metallic Impurities from Off-Grade Copper Concentrate in Alkaline Solution. International Journal of Nonferrous Metallurgy, 7, 9 23. https://doi.org/10.4236/ijnm.2018.72002

[12] Rebodello, C. and Parra, N. (2019) Trends and Treatment of Arsenic in Copper Mining; EcoMetales Limited: Región Metropolitana, Chile, 2019.

[13] Fujita, T., Fujieda, S., Shinoda, K. and Suzuki, S. (2012) Scorodite Solubility and Storage Management System for Arsenic-Bearing Compounds. In: Wang, S., Dutrizac, J.E., Free, M.L., Hwang, J.Y. and Kim, D., Eds., T.T. Chen Honorary Symposium on Hydrometallurgy, Electrometallurgy and Materials Characterization, The Minerals, Metal \&Materials Society (TMS), Orlando, 407-417. https://doi.org/10.1002/9781118364833.ch36

[14] Twidwell, L. (2019) Treatment of Arsenic-Bearing Minerals and Fixation of Recovered Arsenic Products: A Review. Society for Mining, Metallurgy \& Exploration, Englewood.

[15] Adham, K., Lee, C., Francey, S. and Hussein, A. (2019) A Comparison of Roasting Technologies for Arsenic Removal from Copper Concentrates. Proceedings of the COPPER CU2019, Vancouver, 18-21 August 2019, Proceeding 538079.

[16] Rios, G., Ruiz, I., Cruells, M. and Roca, A. (2019) Leaching of Copper Flush Furnace Dust with Week Acid Bleed and Arsenic Precipitations as Scorodite and Arsenical Jarosite. Proceedings of the COPPER CU2019, Vancouver, 18-21 August 2019, Proceeding 591168.

[17] Parra, R., Sepúlveda, X., Wilkomirsky, I., Parada, F. and Balladares, E. (2012) Proceso para la Remoción de Arsénico, Antimonio y Bismuto Desde Polvos de Fundición de Cobre, que Comprende Mezclado de los Polvos de Fundición con un Agente Sulfidizante, Aglomeración de la Mezcla, Sulfidización de los Compuestos Arsenicales, Volatilización y Condensación de los Sulfuros de Arsénico. Chilean Patent No. CL 2012-001376, 30 November 2012.

[18] Yang, T., Chen, L., Liu, W., Hao, Z., Zhang, D., Xiao, Q. and Rao, S. (2015) Method for Separating and Arsenic from Arsenic-Containing Soot. Chinese Patent No. CN 
104294053 B, 21 January 2015.

[19] Xu, B., Shi, T., Yang, B., Jiang, W., Yang, J., Liu, D., Deng, Y., Xiong, H., Li, Y. and $\mathrm{Qu}, \mathrm{T}$. (2019) Method for Removing Arsenic from Arsenic-Containing Soot. Chinese Patent No. CN 109136576 A, 4 January.

[20] Guentner, J., Wrobel, M., Charitos, A., Hammerschmidt, J. and Nurgaliyeva, D. (2016) Treatment of As-Containing Flue Dust from Copper Flash Smelter. Proceedings of the Copper 2016, Kobe, 13-16 November 2016, Proceeding PY5-5.

[21] Specht, A., Kadereit, H., Schmidt, J. and Hoppe, M. (2013) Method and Device for Processing Flue Dust. U.S. Patent No. US 2013/0047788 A1. (28, 2, 2013).

[22] Randall, P. (2012) Arsenic Encapsulation Using Portland Cement with Ferrous Sulfate/Lime and Terra-Bond Technologies-Microcharacterization and Leaching Studies. Science of the Total Environment, 420, 300-312. https://doi.org/10.1016/j.scitotenv.2011.12.066

[23] Padilla, R., Fan, Y. and Wolkomirsky, I. (2001) Decomposition of Enargite in Nitrogen Atmosphere. Canadian Metallurgical Quarterly, 40, 335-342. https://doi.org/10.1179/cmq.2001.40.3.335

[24] Wilkomirsky, I., Parra, R., Parada, F. and Balladares, E. (2014) Physico-Chemistry and Kinetics Mechanisms of Partial Roasting of High-Arsenic Copper Concentrates. Proceedings of the Copper 2013, Santiago, 1-4 December 2013, 539-552.

[25] Yamazaki, N. (2018) Trends of Arsenic in Copper Raw Materials and Its Technical Countermeasure in the Copper Industry. Proceedings of the International Seminar on Impurities in Copper Raw Materials, Tokyo, 16-17 October 2018.

[26] Wilkomirsky, I., Parra, R., Parada, F., Balladares, E. and Seguel, E. (2019) Roasting of High Arsenic Copper Concentrates: Kinetics and Mechanisms of Calcine Formation. Proceedings of the COPPER CU2019, Vancouver, 18-21 August 2019, Proceeding 589693. 


\section{Annex 1}

Additional information of characterization of copper concentrate with high concentration of arsenic (Tables A1-A3, Figure A1 and Figure A2).

Table A1. The Quantitative Evaluation of Minerals by QEMSCAN analysis of the copper concentrate (analysis conditions: Probe current $=4.55 \mathrm{nA}$, beam intensity: $25 \mathrm{kV}$ ).

\begin{tabular}{cccc}
\hline $\begin{array}{c}\text { Normalized } \\
\text { Mineralogical Composition }\end{array}$ & \multicolumn{2}{c}{$\begin{array}{c}\text { Normalized } \\
\text { Elemental Composition }\end{array}$} \\
\hline Phase & $(\mathrm{wt} \%)$ & Element & $(\mathrm{wt} \%)$ \\
\hline Chalcocite/Digenite & 36.1 & $\mathrm{Cu}$ & 46.9 \\
Enargite/Tennantite & 30.5 & $\mathrm{~S}$ & 32.5 \\
Pyrite & 24.4 & $\mathrm{Fe}$ & 13.0 \\
Chalcopyrite & 3.2 & $\mathrm{As}$ & 5.8 \\
Bornite & 2.5 & $\mathrm{O}$ & 0.8 \\
Covellite & 0.7 & $\mathrm{Zn}$ & 0.4 \\
Quartz & 0.7 & $\mathrm{Si}$ & 0.4 \\
Sphalerite & 0.6 & $\mathrm{Al}$ & 0.1 \\
Hematite/Magnetite & 0.4 & $\mathrm{Ca}$ & 0.1 \\
Tenorite & 0.2 & $\mathrm{~K}$ & 0.02 \\
Calcite, clay, alunite, others & 0.65 & Others & 0.05 \\
\hline
\end{tabular}

Table A2. Atomic absorption analysis of the copper concentrate with high concentration of arsenic.

\begin{tabular}{ccccc}
\hline \multicolumn{5}{c}{ Concentration (wt\%) } \\
\hline $\mathrm{Cu}$ & $\mathrm{Fe}$ & $\mathrm{As}$ & $\mathrm{S}$ & Insoluble \\
\hline 42.1 & 11.1 & 5.23 & 30.0 & 11.6
\end{tabular}

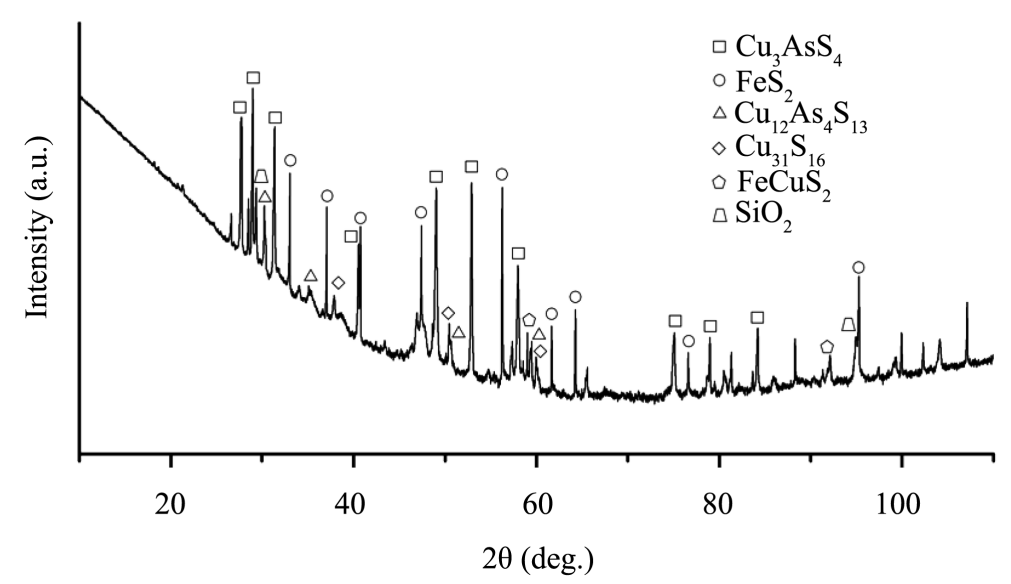

Figure A1. XRD analysis of the copper concentrate (analysis conditions: $t / s t e p=17$ s, step $=2.1,2 \theta=10-100$, time $=15 \mathrm{~min})$. 

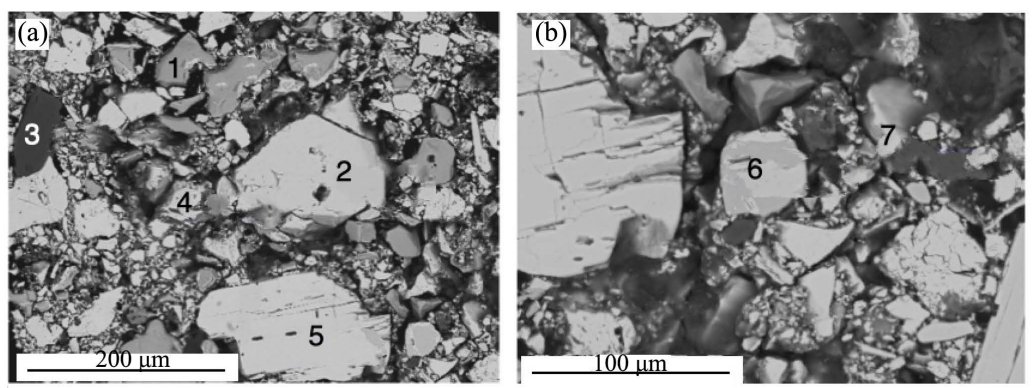

Figure A2. Scanning electron micrographs of a copper concentrate. (a) EDS analyzed points of $\mathrm{FeS}_{2}, \mathrm{ZnS}, \mathrm{SiO}_{2}, \mathrm{Cu}_{2} \mathrm{~S}$ and $\mathrm{Cu}_{3}(\mathrm{As}, \mathrm{Sb}) \mathrm{S}_{4}$ phases, (b) EDS analyzed points of $\mathrm{CuFeS}_{2}$ and $\mathrm{Cu}_{3} \mathrm{AsS}_{4}$ phases.

Table A3. Phases of the copper concentrate and their elemental composition analyzed by EDS (analysis condition: Acceleration voltage $=15 \mathrm{kV}$, beam current $=11 \mathrm{nA}$ ).

\begin{tabular}{cccccccccc}
\hline \multirow{2}{*}{$\mathbf{N}^{\bullet}$} & Phase & \multicolumn{7}{c}{ Normalized Composition (wt\%) } \\
\cline { 3 - 9 } & & $\mathbf{O}$ & $\mathrm{Si}$ & $\mathrm{S}$ & $\mathrm{Fe}$ & $\mathrm{Cu}$ & $\mathrm{Zn}$ & $\mathrm{As}$ & $\mathrm{Sb}$ \\
\hline 1 & $\mathrm{FeS}_{2}$ & 0.0 & 0.0 & 55.7 & 43.5 & 0.7 & 0.0 & 0.1 & 0.0 \\
2 & $\mathrm{ZnS}$ & 0.0 & 0.0 & 34.4 & 0.3 & 0.3 & 64.9 & 0.0 & 0.1 \\
3 & $\mathrm{SiO}_{2}$ & 52.6 & 46.4 & 0.0 & 0.1 & 0.7 & 0.0 & 0.2 & 0.0 \\
4 & $\mathrm{Cu}_{2} \mathrm{~S}$ & 2.6 & 0.2 & 22.0 & 0.5 & 74.7 & 0.0 & 0.0 & 0.0 \\
5 & $\mathrm{Cu}_{3}\left(\mathrm{As}, \mathrm{Sb}_{2} \mathrm{~S}_{4}\right.$ & 0.0 & 0.0 & 34.1 & 0.0 & 46.3 & 0.0 & 15.1 & 4.5 \\
6 & $\mathrm{CuFeS}_{2}$ & 0.0 & 0.0 & 36.6 & 29.8 & 33.5 & 0.0 & 0.1 & 0.0 \\
7 & $\mathrm{Cu}_{3} \mathrm{AsS}_{4}$ & 0.0 & 0.0 & 35.4 & 0.5 & 47.2 & 0.0 & 16.9 & 0.0 \\
\hline
\end{tabular}

\section{Annex 2}

Additional information of characterization of FS dust (Figure A3).

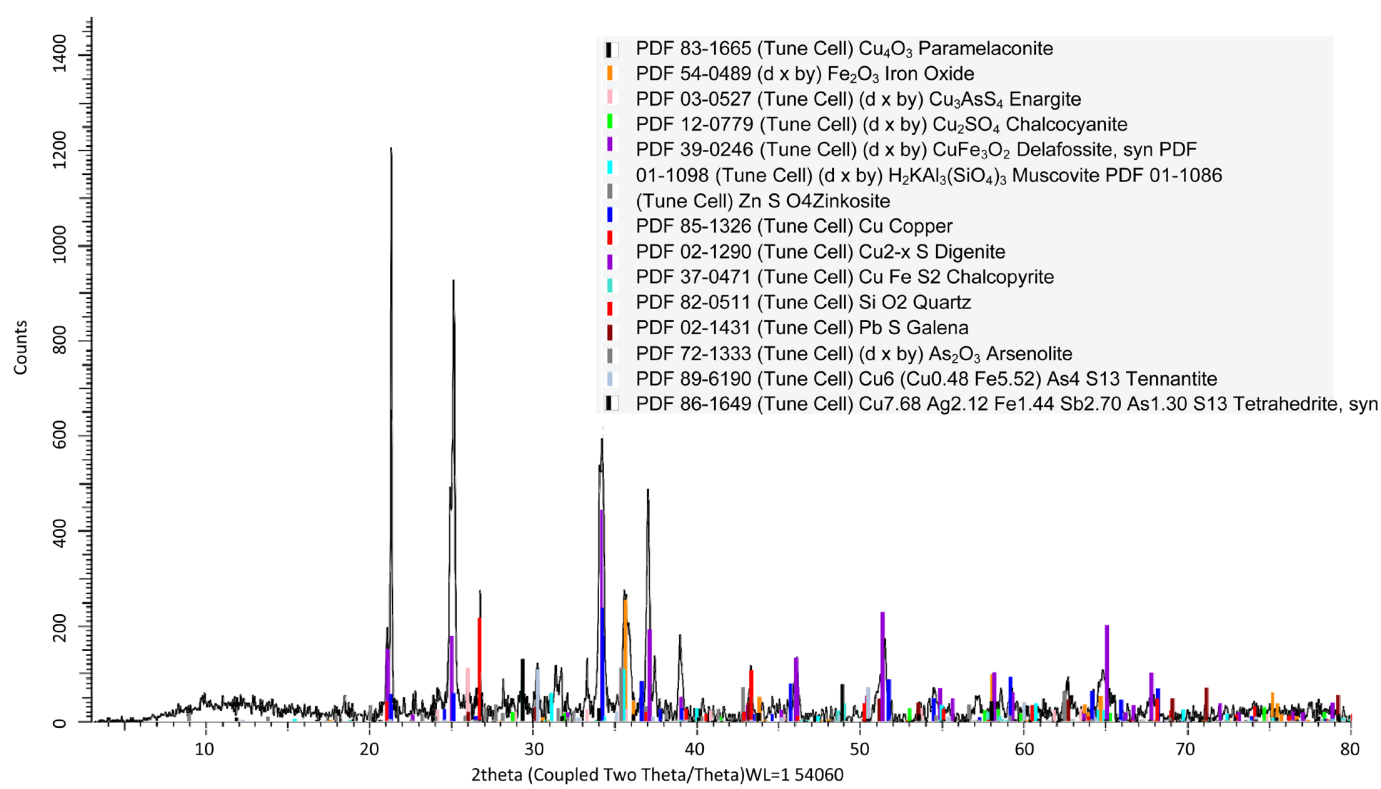

Figure A3. XR-D analysis of FS dust. 


\section{Annex 3}

Additional information of roasting experiment of copper concentrate with high concentration of arsenic (Table A4 and Table A5).

Table A4. Volatilization of arsenic for the copper concentrate under different conditions of temperature and time of the roasting process.

\begin{tabular}{|c|c|c|c|c|c|c|c|c|}
\hline \multirow{3}{*}{ Experiment } & \multicolumn{2}{|c|}{$\begin{array}{c}\text { Experimental } \\
\text { Conditions }\end{array}$} & \multicolumn{5}{|c|}{ Chemical Analysis (wt\%) } & \multirow{3}{*}{ Volatilization } \\
\hline & Temperature & Time & \multirow{2}{*}{$-\mathrm{Cu}$} & \multirow{2}{*}{$\mathrm{Fe}$} & \multirow{2}{*}{ As } & \multirow{2}{*}{$S$} & \multirow{2}{*}{ Insoluble } & \\
\hline & $\left({ }^{\circ} \mathrm{C}\right)$ & $(\min )$. & & & & & & \\
\hline 1 & 600 & -- & 46.2 & 10.2 & 5.50 & 27.8 & 10.1 & 0.0 \\
\hline 2 & 600 & 2 & 42.5 & 10.2 & 4.26 & 26.4 & 9.38 & 22.5 \\
\hline 3 & 600 & 5 & 45.0 & 11.6 & 0.44 & 21.0 & 13.1 & 92.0 \\
\hline 4 & 600 & 15 & 45.8 & 11.3 & 0.40 & 17.9 & 12.8 & 92.7 \\
\hline 5 & 600 & 30 & 39.6 & 10.3 & 0.41 & 12.1 & 14.5 & 92.5 \\
\hline 6 & 650 & 2 & 46.3 & 11.0 & 3.64 & 23.8 & 7.94 & 33.8 \\
\hline 7 & 650 & 5 & 46.4 & 10.6 & 0.45 & 24.4 & 12.0 & 91.8 \\
\hline 8 & 650 & 15 & 48.7 & 11.3 & 0.23 & 18.4 & 10.4 & 95.8 \\
\hline 9 & 650 & 30 & 43.7 & 10.6 & 0.25 & 12.6 & 13.3 & 95.5 \\
\hline 10 & 700 & 2 & 45.4 & 10.8 & 2.25 & 24.1 & 8.52 & 59.1 \\
\hline 11 & 700 & 5 & 47.7 & 11.8 & 1.65 & 23.6 & 6.58 & 70.0 \\
\hline 12 & 700 & 15 & 48.8 & 11.7 & 0.85 & 18.6 & 6.96 & 84.5 \\
\hline 13 & 700 & 30 & 45.1 & 11.6 & 0.22 & 7.32 & 13.4 & 96.0 \\
\hline
\end{tabular}

Table A5. QEMSCAN analysis of the roasted copper concentrate at $650^{\circ} \mathrm{C}$ and $15 \mathrm{~min}$ of roasting (experiment 8 ) (analysis conditions: Probe current $=4.55 \mathrm{nA}$, beam intensity: 25 $\mathrm{kV})$.

\begin{tabular}{cccc}
\hline Normalized Mineralogical Composition & \multicolumn{2}{c}{ Normalized Elemental Composition } \\
\hline Phase & $(\mathrm{wt} \%)$ & Element & (wt\%) \\
\hline Bornite & 63.5 & $\mathrm{Cu}$ & 55.5 \\
Chalcopyrite & 6.6 & $\mathrm{~S}$ & 20.7 \\
Chalcocite & 6.2 & $\mathrm{Fe}$ & 12.6 \\
Tenorite & 5.0 & $\mathrm{O}$ & 7.2 \\
Quartz & 4.7 & $\mathrm{Si}$ & 2.4 \\
Brochantite/Antlerite & 4.6 & $\mathrm{Zn}$ & 0.6 \\
Hematite/Magnetite & 3.9 & $\mathrm{As}$ & 0.5 \\
Clinoclase & 1.4 & $\mathrm{Cl}$ & 0.2 \\
\hline
\end{tabular}




\section{Continued}

\begin{tabular}{cccc}
\hline Cuprite & 1.1 & $\mathrm{Al}$ & 0.2 \\
Chenevixite & 0.9 & Others & 0.3 \\
Sphalerite & 0.8 & & \\
Mica & 0.4 & \\
Enargite/Tennantite & 0.2 & \\
Others & 0.7 & \\
\hline
\end{tabular}

\section{Annex 4}

Additional information of roasting experiment of mixtures of copper concentrate/FS dust (Table A6 and Table A7).

Table A6. Volatilization of arsenic for different weight ratios of the copper concentrate/FS dust mixture, at $650^{\circ} \mathrm{C}$ and $15 \mathrm{~min}$ of the roasting process.

\begin{tabular}{ccc}
\hline Experiment & Ratio Copper concentrate/FS dust & As Volatilization (\%) \\
\hline 14 & $0 / 100$ & 0 \\
15 & $10 / 90$ & 0 \\
16 & $30 / 70$ & 0 \\
17 & $50 / 50$ & 51.1 \\
18 & $75 / 25$ & 84.3 \\
19 & $80 / 20$ & 91.8 \\
20 & $90 / 10$ & 93.0 \\
21 & $100 / 0$ & 95.9 \\
\hline
\end{tabular}

Table A7. QEMSCAN analysis of roasting of a mixture of a copper concentrate/FS dust for experiment at $700^{\circ} \mathrm{C}, 15$ minutes, ratio concentrate/FS dust 75/25 (analysis conditions: Probe current $=4.55 \mathrm{nA}$, beam intensity: $25 \mathrm{kV}$ ).

\begin{tabular}{cccc}
\hline Normalized Phase Composition & \multicolumn{2}{c}{ Normalized Elemental Composition } \\
\hline Phase & $(\mathbf{w t} \%)$ & Phase & (wt\%) \\
\hline Tenorite & 32.9 & $\mathrm{Cu}$ & 48.5 \\
Brochantite/Antlerite & 20.6 & $\mathrm{O}$ & 22.0 \\
Bornite & 17.1 & $\mathrm{Fe}$ & 12.6 \\
Quartz & 12.3 & $\mathrm{~S}$ & 8.2 \\
Hematite/Magnetite & 9.9 & $\mathrm{Si}$ & 6.0 \\
Chalcocite & 3.6 & $\mathrm{Cl}$ & 1.0 \\
Cuprite & 1.2 & $\mathrm{Zn}$ & 0.8 \\
Mica & 0.7 & $\mathrm{H}$ & 0.4 \\
Sphalerite & 0.4 & Others & 0.5 \\
\hline
\end{tabular}




\section{Continued}

Chalcopyrite

Others
0.3

1.1

Note: Arsenic was not reported in Table A7 because it was outside the detection limit of the equipment. 